\title{
Victims of Our Own Success: The Perils of Obergefell and Windsor
}

\author{
ANTHONY C. INFANTI* \\ TABLE OF CONTENTS
}

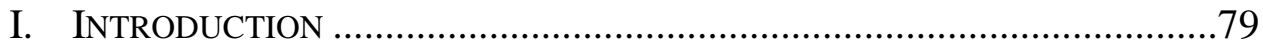

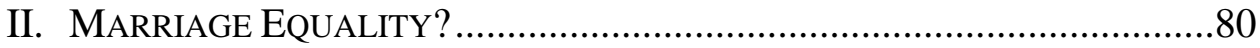

III. MARRIAGE—AND ONLY MARRIAGE! ...............................................82

IV. CONCLUSION...................................................................... 85

\section{INTRODUCTION}

The recent U.S. Supreme Court ruling in Obergefell v. Hodges ${ }^{1}$ that legalized same-sex marriage in all fifty states is an important victory in the battle for LGBT rights, as was the Court's companion decision two years earlier in United States $v$. Windsor ${ }^{2}$ that required the federal government to recognize same-sex marriages. Despite their importance, however, these victories come with their own set of perils for the LGBT rights movement. In this essay, I acknowledge and describe some of these perils.

Certain of the perils are already well understood and result from strategic choices made to obtain these two victories. ${ }^{3}$ Other perils are less widely known but are equally troubling. In this essay, I use the lens of tax law to sketch some of these lesser known perils in an effort to make them more concrete-and, I hope, more easily and widely understood. Although tax law is only one potential lens, it is an important and powerful one because it touches every aspect of life and the law, giving it a unique magnetic and magnifying power for analyzing interactions between law and society.

\footnotetext{
* Senior Associate Dean for Administration and Special Projects and Professor of Law, University of Pittsburgh School of Law.

${ }^{1}$ Obergefell v. Hodges, 135 S. Ct. 2584, 2608 (2015).

2 United States v. Windsor, 133 S. Ct. 2675, 2696 (2013).

${ }^{3}$ For example, those engendered by seeking marriage equality before working to obtain legal protection against discrimination on the basis of sexual orientation and gender identity or expression in most states. See Anthony C. Infanti, Forget Reading the Tea Leaves on Marriage Equality, HufFington Post (Apr. 29, 2015, 12:38 PM), http://www.huffingtonpost.com/anthony-c-infanti/forget-reading-the-tea-leaves-on-marriageequality_b_7171942.html [http://perma.cc/3SNF-EYJK]. At present, a majority of states lack these legal protections, which means that a couple availing themselves of their constitutional right to marry on one day can be fired the next for having entered into a same-sex marriage. For a compendium of state legal protections in these areas, see Maps of State Laws \& Policies, HuM. RTS. CAMPAIGN, http://www.hrc.org/state_maps [http://perma.cc/JLZ6-4B9D].
} 


\section{MARRIAGE EQUALITY?}

One peril is the false sense of security that Supreme Court victories can create, making it seem that the legal fight for marriage equality is now over. This happens when we confuse Supreme Court decisions that bestow formal equality on same-sex couples with actual equal treatment of married same-sex and different-sex couples. Though the Obergefell and Windsor decisions clearly advance the equal treatment of same-sex couples significantly, it will take much more work to fully achieve equal treatment of those couples who decide to marry.

For a century, our federal tax laws were created, amended, and revised in a world in which heteronormativity has been —and, even now, still is — dominant. Moreover, this heteronormativity has not only been a core building block of the federal tax system but also a key feature of the state laws that underpin our federal tax system. It is easy to forget, but many federal tax questions turn on the prior application of state law. ${ }^{4}$ For instance, without an effective transfer of property under state law or the payment of damages to settle a tort liability or the payment of support in satisfaction of a state divorce decree, there would be nothing for the federal tax law to operate upon. Or, put more colorfully, "[w]ithout the body of state law prescribing the rights and liabilities arising from taxpayers' daily activities, the federal tax collector would be a fish out of water."5

The compound heteronormativity of state and federal law readily surfaces when considering the taxation of family formation. Viewed from a heteronormative perspective, procreation occurs between a man and a woman and should only need outside assistance when either the man or the woman (or both of them) have fertility issues that prevent "natural" procreation. Considering the heteronormativity of the federal tax laws, it should be no surprise then that the tax incentives relating to procreation come solely in the form of a deduction for medical expenses. ${ }^{6}$

Unlike different-sex couples - who are the only ones that come to mind when taking this heteronormative perspective-same-sex couples always need assistance to procreate. In particular, gay couples need the help of a surrogate and perhaps an egg donor to procreate. The procedures involved in obtaining this assistance are the same "medical" procedures that would be used by a differentsex couple in which the woman is unable to carry a child due to fertility problems. However, as I have explained at length elsewhere, even though the quite costly surrogacy-related expenses incurred by the infertile different-sex couple would likely qualify for deduction, the same costly surrogacy expenses

41 Boris I. BitTKER \& LAWRENCE LOKKEN, FEDERAL TAXATION OF INCOME, ESTATES, AND GIFTS \ 4.1 (3d ed. 1999) (“[T]he Code’s reliance on state law is so pervasive that it rarely rises to the conscious level.”).

${ }^{5}$ Id.

6 Anthony C. Infanti, The House of Windsor: Accentuating the Heteronormativity in the Tax Incentives for Procreation, 89 WASH. L. REV. 1185, 1215-20 (2014). 
incurred by the gay couple clearly would not. ${ }^{7}$ These couples are similarly situated because neither can procreate without medical assistance. Yet they are treated differently, based solely on their sexual orientation, because of the heteronormative assumption that only different-sex couples do (and ought to) procreate, which "naturally" renders infertility the only valid reason for seeking assistance to procreate. As a result, the federal tax laws validate and likely financially support procreation by the different-sex couple while simultaneously denying that same validation and financial support to the gay couple, stigmatizing them and perhaps creating an insuperable financial hurdle to procreation. $^{8}$

Married lesbian couples who wish to procreate also need medical assistance, but of a different kind. They need to obtain a sperm donor and often avail themselves of a doctor's assistance with artificial insemination. The biological mother who gives birth to the child conceived through artificial insemination will be treated as the legal mother of the child. But what of the "other" mother? When a married different-sex couple resorts to artificial insemination to procreate, state law usually presumes the husband to be the legal father of the child. ${ }^{9}$ Notwithstanding that this presumption is written in a gendered fashion, some states have extended this presumption of parenthood to the "other" mother in a married lesbian couple. ${ }^{10}$ Other states resist the application of this presumption to married lesbian couples. ${ }^{11}$

If a lesbian couple is unable to avail themselves of this presumption of parentage, then they must go through a stepparent adoption in order for both spouses to be legally recognized as parents. An adoption proceeding is, of course, more intrusive and expensive than merely placing both spouses' names on a child's birth certificate. Disappointingly, rather than mitigating — or at the very least, rejecting any role as an accomplice to-overt discrimination on the basis of sexual orientation, the federal tax laws actually exacerbate this discriminatory treatment.

The federal adoption tax credit and the exclusion for employer-provided adoption assistance programs provide financial support to encourage bringing children into a family through adoption. ${ }^{12}$ Both of these provisions explicitly deny financial support to adoptions that merely add a new parent to an existing family. ${ }^{13}$ Even though a lesbian couple who pursues adoption because of the

${ }^{7}$ Id. at $1222-29$.

${ }^{8}$ Id. at $1230-31$.

${ }^{9}$ E.g., MASS. ANN. LAwS ch. 46, § 4B (LexisNexis 2006) (establishing a presumption of parenthood in the case of married different-sex couple's use of artificial insemination).

${ }^{10}$ E.g., Della Corte v. Ramirez, 961 N.E.2d 601, 602-03 (Mass. App. Ct. 2012) (applying the presumption to a married lesbian couple).

${ }^{11}$ Associated Press, Couple Heads to Court to Get 2 Moms on Birth Certificate, LAS VEGAS Sun (July 15, 2015), http://lasvegassun.com/news/2015/jul/15/couple-heads-to-court-toget-2-moms-on-birth-certi/ [http://perma.cc/MY9N-JXL4].

12 I.R.C. $\S \S 23,137$ (2012).

${ }^{13}$ Id. § 23(d)(1)(C); see also id. § 137(d) (incorporating § 23(d) by reference). 
unavailability of the presumption of parentage is, in fact, perfecting a new family relationship with a child rather than adding a new parent to a preexisting family relationship, the couple is nonetheless denied the benefit of the federal adoption tax credit and the exclusion for employer-provided adoption assistance because the perfection of the family relationship is accomplished through a stepparent adoption. ${ }^{14}$ This disparate treatment of the lesbian couple is implicitly based on the heteronormative view that adoption only needs to occur either when (1) a child is being removed from one set of (heterosexual) parents and being placed with another or (2) a (heterosexual) stepparent is added to a preexisting family relationship that ended through death or divorce. No thought is given to the fact that same-sex couples must sometimes avail themselves of adoption because both of the child's initial set of parents are neither the actual nor presumptive biological parents of the child. ${ }^{15}$

There is obviously still much work to be done to eradicate the vestiges of heteronormativity that remain in our laws if we are truly to treat married samesex and different-sex couples equally. And, as discussed more fully below, we should simultaneously be concerned with addressing the ways in which support for procreation and family formation are linked to marriage rather than to the broader goal of fostering loving families of whatever shape and size.

\section{MARRIAGE—AND ONLY MARRIAGE!}

In addition to blinding us to gaps between the promise of equality and the reality of persistent unequal treatment, the Obergefell and Windsor decisions have reified the privileged position of marriage in our laws. The focus on the narrow goal of achieving marriage equality through this litigation has not only cost us an opportunity to push for more meaningful improvement in the law, but it has actually set back the movement for equal legal treatment of all regardless of relationship status. Relationship-neutral laws would improve the lives of all segments of the LGBT community (and not just those interested in marrying), would help others outside of the LGBT community, and would remove the legal incentives for individuals to enter into a relationship status (i.e., marriage) that they might not otherwise choose.

A significant focus of the argument for marriage equality was equal access to the tax benefits that are available to married couples. Indeed, the Windsor case itself was a dispute about the ability of a surviving same-sex spouse to avail herself of the estate tax marital deduction so that she could avoid paying a $\$ 363,053$ federal tax bill. ${ }^{16}$ More commonly, the proponents of marriage equality

\footnotetext{
${ }^{14}$ Id. § 23(d)(1)(C); see also id. § 137(d) (incorporating § 23(d) by reference).

15 Gay couples experience a similar issue when procreating with the help of a surrogate. See Infanti, supra note 6, at 1219-20.

${ }^{16}$ United States v. Windsor, 133 S. Ct. 2675, 2683 (2013). Unfortunately, these arguments too often elided the far more complicated story of how the tax laws treat marriage, focusing entirely on the tax benefits of marriage and ignoring the tax detriments that accompany marriage. See, e.g., Katherine Franke, A Progressive Agenda for Married Queers,
} 
cited the inability of same-sex couples to file joint income tax returns at the state and federal levels when making the case for extending marriage to same-sex couples. ${ }^{17}$

For decades, however, tax academics concerned by the intersection of tax and gender have highlighted the adverse impact of treating the married couple as a single economic unit for tax purposes. ${ }^{18}$ They have explored how the tax laws create a disincentive for secondary earners - a group perceived as being largely composed of women-from entering the paid labor force and instead encourage them to perform unpaid labor in the home. ${ }^{19}$ This line of inquiry has led many to argue for a marriage-neutral tax system; that is, against the joint income tax return and in favor of its replacement with a system of mandatory individual filing. ${ }^{20}$ I count myself among this group of academics, as I have developed a proposal that would take our tax system a step further by making it not just marriage neutral but relationship neutral, allowing taxpayers complete freedom to choose who will be treated as their family for tax purposes. ${ }^{21}$

Yet, contrary to the trend toward arguing that marriage should be made less important for tax purposes, the marriage equality movement has only made it more so. With its intent focus on achieving marriage equality (and nothing less or different), the LGBT rights movement has not only stanched efforts to erode the importance of marriage and marital status in the tax laws but it has actually made marriage even more important than it had been. ${ }^{22}$

SLATE: OUTWARD (June 30, 2015, 11:17 AM), http:/www.slate.com/blogs/outward/2015/ 06/30/same_sex_marriage_and_progressive_politics_can_they_coexist.html [http://perma.cc/ UA5Q-7ZA7].

${ }^{17}$ E.g., Bostic v. Schaefer, 760 F.3d 352, 369 (4th Cir. 2014) (joint state tax returns); id. at 387 (Niemeyer, J., dissenting) (same); Kitchen v. Herbert, 755 F.3d 1193, 1199, 1203 (10th Cir. 2014) (same); Gill v. Office of Pers. Mgmt., 699 F. Supp. 2d 374, 383 (D. Mass 2010) (joint federal tax returns), aff'd sub nom. Massachusetts v. U.S. Dep't of Health \& Human Servs., 682 F.3d 1 (1st Cir. 2012).

${ }^{18}$ For the earliest contribution to this line of inquiry, see generally Grace Blumberg, Sexism in the Code: A Comparative Study of Income Taxation of Working Wives and Mothers, 21 BUFF. L. REV. 49 (1971).

${ }^{19}$ See generally Marjorie E. Kornhauser, Love, Money, and the IRS: Family, Income Sharing, and the Joint Income Tax Return, 45 HASTINGS L.J. 63 (1993); Edward J. McCaffery, Taxation and the Family: A Fresh Look at Behavioral Gender Biases in the Code, 40 UCLA L. REV. 983 (1993).

${ }^{20}$ For a summary of the critiques of joint filing, see Anthony C. Infanti, Decentralizing Family: An Inclusive Proposal for Individual Tax Filing in the United States, 2010 UTAH L. REV. 605, 614-18.

21 See id. at 638-63.

22 And the advocates of marriage equality have had significant rhetorical assistance in this regard from the Supreme Court. The Court's majority opinions in both Obergefell and Windsor extol the virtues and importance of marriage. These opinions refer to the "transcendent importance of marriage," Obergefell v. Hodges, 135 S. Ct. 2584, 2594 (2015); its promise of "nobility and dignity to all persons, without regard to their station in life," id.; its "centrality ... to the human condition," id.; and the "dignity and status of immense import" conferred by marriage, United States v. Windsor, 133 S. Ct. 2675, 2692 (2013). 
Prior to the Supreme Court's decision in Windsor, the Internal Revenue Service (IRS) expressed a welcome openness to recognizing alternative relationship statuses. In response to an inquiry from H\&R Block, the IRS indicated that a different-sex couple in a civil union or domestic partnership could file a joint federal income tax return if their relationship was legally equivalent to a marriage under state law. ${ }^{23}$ This position was fully in keeping with the foundational tax principle of substance over form. ${ }^{24}$ In other words, "[l]ooking to substance rather than to form, domestic partnerships and civil unions that are marriages all but in name should be treated as marriages for federal tax purposes." 25

But in its post-Windsor guidance, the IRS completely reversed course. It chose to "exalt[] the importance of the 'marriage' label and ignor[e] the legal equivalence of these relationships." 26 Without any supporting reasoning or justification, the IRS stated:

For Federal tax purposes, the terms "spouse," "husband and wife," "husband," and "wife" do not include individuals (whether of the opposite sex or the same sex) who have entered into a registered domestic partnership, civil union, or other similar formal relationship recognized under state law that is not denominated as a marriage under the laws of that state, and the term "marriage" does not include such formal relationships. ${ }^{27}$

By taking this position, the IRS visibly tightened the grip of marriage on the tax laws. Had the IRS reaffirmed its initial position in its post-Windsor guidance, it "could have laid the groundwork for eventually extending recognition to other relationships that entail the same type of entanglement as marriage but come with a more limited set of rights and obligations." 28 That would naturally have opened the door to recognizing a wider array of family relationships, including ones that are not conjugal in nature. But, instead, swept up in the push for "marriage" equality, the IRS decided to disregard core tax principles in favor of a wooden application of the tax laws that cements the legal importance of "marriage" for federal tax purposes.

This is a sorely disappointing result. Many in the LGBT community still face hostility not only from strangers but also from members of their "traditional"

23 Letter from Pamela Wilson Fuller, Senior Technician Reviewer, Treasury Dep’t, to Robert Shair, Senior Tax Advisor, H\&R Block (Aug. 30, 2011), in TAX NEWS TODAY, Nov. 7 , 2011, 2011 TNT 215-62 (LexisNexis).

${ }^{24}$ Estate of H. H. Weinert v. Comm'r, 294 F.2d 750, 755 (5th Cir. 1961) (“The principle of looking through form to substance . . . is the cornerstone of sound taxation ....”).

${ }^{25}$ Anthony C. Infanti, The Moonscape of Tax Equality: Windsor and Beyond, 108 Nw. U. L. REV. 1115, 1130 (2014).

${ }^{26}$ Id.

${ }^{27}$ Rev. Rul. 2013-17, 2013-38 I.R.B. 201, 204.

28 Infanti, supra note 25 , at 1133. 
families. Estranged from some or all of their family members, these LGBT individuals have created families of choice as a substitute for the ones that they were born or adopted into. Following Obergefell and Windsor, married same-sex couples have now been assimilated into the "traditional" family fold; however, the "nontraditional" families of choice continue to be left out in the legal cold. Because of the narrow focus on "marriage" equality, we have lost an opportunity to work for legal change that would have helped all members of the LGBT community (not to mention everyone else!) by making the tax (and our other) laws relationship neutral, thereby rendering the distinction between "traditional" and "nontraditional" families obsolete.

\section{CONCLUSION}

The Supreme Court decisions in Obergefell and Windsor have been celebrated as landmark victories for the LGBT rights movement. But, as I have demonstrated in this essay, there is still much work to be done. These two important victories are adulterated by perils that portend the need for additional legal reforms that will redound to the benefit of all within and without the LGBT community. Let's turn to that work without delay. 